\title{
TINJAUAN YURIDIS TERHADAP PEMASARAN KOSMETIK ILEGAL SECARA ONLINE DI INDONESIA
}

\author{
Febri Jaya ${ }^{1}$
}

\begin{abstract}
The writer's purpose in conducting research on online marketed illegal cosmetics in Indonesia, in particular is to analyse and examine how the development of technology combined with the cosmetics industry is now growing because of the many individuals interested in cosmetics, especially women who want to beautify themselves with the aim of maximizing their self-confidence.

This makes business actors often take advantage of their opportunities to produce and establish cosmetics businesses with the requirements given by the state. Business actor must have permission to produce, distribute and of course with the right quality standards, but in fact some business actors assume the requirements given are difficult and the process is time-consuming. Then the negative impacts arising from this matter is business actor or producer of production and distribution cosmetics has not tested products in laboratory, thus, it is fake and could be dangerous. Of course, this also has an impact on consumers who are exultant with illegal cosmetics and skincare products because they are tempted by massive promotions and discounts however it may cause people suffering losses due to illegal cosmetics offered in the market without correct information by cosmetic businesses.

Keywords: E-commerce, Consumer Protection, and illegal Cosmetics
\end{abstract}

\begin{abstract}
Abstrak
Tujuan penulis dalam melakukan penelitian terhadap kosmetik ilegal yang dipasarkan secara online di Indonesia adalah untuk menganalisis dan memeriksa bagaimana perkembangan teknologi yang dikombinasikan dengan industri kosmetik sekarang berkembang karena banyaknya individu yang tertarik pada kosmetik, terutama wanita yang ingin mempercantik diri. dengan tujuan memaksimalkan kepercayaan diri mereka.

Hal ini membuat pelaku bisnis sering memanfaatkan peluang mereka untuk memproduksi dan membangun bisnis kosmetik dengan persyaratan yang diberikan oleh negara. Pelaku usaha harus memiliki izin untuk memproduksi, mendistribusikan, dan tentu saja dengan standar kualitas yang tepat, tetapi pada kenyataannya beberapa pelaku usaha menganggap persyaratan yang diberikan sulit dan prosesnya memakan waktu. Maka dampak negatif yang timbul dari hal ini adalah pelaku usaha atau produsen kosmetik produksi dan distribusi belum menguji produk di laboratorium, sehingga palsu dan bisa berbahaya. Tentu saja, ini juga berdampak pada konsumen yang senang dengan kosmetik ilegal dan produk perawatan kulit karena mereka
\end{abstract}

\footnotetext{
${ }^{1}$ Dosen Program Sarjana Hukum Universitas Internasional Batam
} 
tergoda oleh promosi dan diskon besar-besaran namun hal itu dapat menyebabkan orang menderita kerugian karena kosmetik ilegal yang ditawarkan di pasar tanpa informasi yang benar oleh bisnis kosmetik

\section{Kata Kunci : e-commerce, perlindungan konsumen, kosmetik illegal}

\section{A. Latar Belakang Masalah}

Di Indonesia, perederan dan perkembangan industri kecantikan diakui cukup pesat belakangan ini sehingga memiliki potensi terhadap pasar yang cukup besar pada tahun 2017 lalu, Kementerian Perindustrian mengatakan bahwa peningkatan industri kosmetik nasional tercatat mencapai 20 persen akibat dari permintaan pasar yang melunjak sehingga Kementerian Perindustrian menetapkan industri kosmetik merupakan sektor andalan. Namun, kosmetik yang banyak diedarkan dipasaran mempunyai merek yang berbeda-beda apabila dilihat dari kualitas dan harga produk itu sendiri.

Keinginan yang tinggi pada kaum wanita untuk membeli kosmetik tidak sebanding dengan pengetahuan mereka tentang bagaimana memilih kosmetik yang baik, asli dan pastinya aman, melainkan banyaknya wanita yang memilih jalan alternatif seperti ingin mendapatkan wajah cantik dengan jenis kosmetik yang dibeli dengan instan, harga murah dan khasiatnya cepat dan terlihat sama seperti produk kosmetik yang asli dan mahal, akan tetapi banyak kasus bermunculan dimana pemakaian dari krim wajah dapat memperburuk kondisi kulit pada wajah kita, membeli tanpa mempertimbangkan kelayakan dan keaslian pada produk kosmetik adalah hal yang tidak wajar, konsumen kosmetik sering sekali didapati tidak meneliti sebuah produk terlebih dahulu sebelum membeli. ${ }^{2}$

Padahal ada kemungkinan terkandung alasan-alasan tertentu mengapa satu produk kosmetik tersebut dijual murah, seperti misalnya kosmetik tersebut tidak diregistrasikan sehingga tidak mendapatan ijin dari Badan Pengawas Obat dan Makanan (BPOM), terkandung bahan-bahan berbahaya yang dapat merusak organ tubuh manusia, tidak berlabel ataupun tidak memiliki tanggal kadaluarsa produk sampai dengan menggunakan merk kosmetik ternama kemudian menjual produk kosmetik tersebut jauh lebih murah. ${ }^{3}$

Menyinggung soal pemasaran dan peredaran produk kosmetik, produsen atau pelaku usaha dapat melakukan segala cara untuk menarik para pelanggan untuk memperoleh keuntungan sebesar mungkin atas produk yang dijualnya. Para pelaku usaha kerap menggunakan media sosial seperti Facebook, Twiter, Instagram, Shopee

\footnotetext{
${ }^{2}$ Deny, Fitra, K. Lestari, Zainal Hakim, "Penggunaan Vitamin E dan Vitamin C Topikal dalam Bidang Kosmetik”, Majalah Kedokteran Andalas (2006): hlm. 41-51.

${ }^{3}$ Aprilianto, R., "Product experience, outcome focus, moments of truth, peaceof mind pengaruhnya terhadap customer satisfaction dan customer loyalty skin care ErhaClinic" (Surabaya, 2016).
} 
dan yang lainnya untuk melakukan jual beli secara online, dengan cara meng-endorse para artis dan selebgram yang mempunyai pengaruh yang cukup besar terhadap followersnya juga sering dilakukan oleh pelaku usaha.

Peningkatan terhadap konsumerisme kosmetik pemutih wajah semakin meningkat khususnya pada remaja putri dan ibu-ibu, para pelaku usaha tidak menyia-nyiakan kesempatan yang dapat mendatangkan keuntungan besar. Kemudian bagaimana jika kemudian diketahui bahwa produk tersebut diproduksi secara tidak aman, ilegal, tidak terdaftar dan berbahaya sehingga merugikan para konsumen dan pelaku usaha, maka terjadi pelanggaran terhadap beberapa peraturan yang berkaitan pada produksi serta peredaran kosmetik ilegal seperti pelanggaran pada Undang-Undang Nomor 33 Tahun 2014 tentang Jaminan Produk Halal, Undang-Undang Nomor 36 Tahun 2009 tentang Kesehatan, dan Undang-Undang Nomor 8 Tahun 1999 tentang Perlindungan Konsumen.

Walaupun begitu, peraturan yang telah ada tetap tidak membawa pengaruh besar terhadap peredaran kosmetik ilegal di Indonesia, karena pada faktanya sampai sekarang ini terjadi peningkatan pada peredaran kosmetik ilegal dari tahun ke tahun. Dari hal ini, penulis ingin sekali meneliti dan memperlajari hal terkait dengan kosmetik yang beredar dijual murah dan mempunyai dampak yang sangat berbahaya contohnya kasus dari efek pada pemakaian krim wajah menyebabkan timbulnya flek hitam yang permanen bahkan obat kecantikan dapat mengakibatkan gagal ginjal hingga kematian serta para pelaku usaha yang meproduksi dan memasarkan tidak sesuai dengan ketentuan yang berlau di Indonesia dan adakah hak untuk mendapatkan perlindungan hukum dari orang yang dirugikannya.

\section{B. Rumusan Masalah}

Maka, dari uraian latar belakang diatas, penulis merumuskan tiga rumusan permasalahan sebagai berikut:

1. Bagaimana tanggung jawab pihak yang memproduksi dan mengedarkan kosmetik ilegal di Indonesia?

2. Apa sanksi yang diberikan kepada pelaku usaha yang memasarkan dan mengedarkan kosmetik ilegal secara online di Indonesia?

3. Bagaimanakah perlindungan hukum terhadap konsumen yang mengalami kerugian akibat pemakaian kosmetik ilegal di Indonesia?

\section{Metode Penelitian}

Penelitian merupakan suatu kegiatan berupa pengumpulan data, informasi, fakta, kebenaran ataupun lainnya yang dilakukan oleh seorang atau lebih untuk bisa memecahkan, mengkaji, mengevaluasi suatu rumusan permasalahan ataupun untuk 
bisa memahami suatu keadaan disekitar. ${ }^{4}$ Jenis-jenis penelitian yang dilakukan oleh seorang peneliti didasarkan dan dilangsungkan berdasarkan kondisi, kebutuhan dan rumusan masalah dimiliki oleh masing-masing peneliti agar si peneliti dapat menemukan jawaban dan kebenaran yang dicarinya. ${ }^{5}$ Selain itu, agar peneliti bisa memecahkan suatu rumusan masalah yang dimilikinya, tak jarang bahwa peneliti menyiapkan pertanyaan sebanyak-banyaknya untuk kemudian peneliti berupaya menjawab keseluruhan pertanyaan tersebut.

Untuk memecahkan rumusan masalah yang penulis miliki, penulis memilih untuk menggunakan penelitian normatif. ${ }^{6}$ Penelitian hukum normatif adalah penelitian dengan cara mengumpulkan data, mengkaji lebih dalam terhadap berbagai data yang mendukung penelitian seperti peraturan perundang-undangan, teori, putusan pengadilan hingga bagian kepustakaan untuk mengkaji penelitian tersebut. peneliti melakukan "bedah perpustakaan" untuk bisa memenuhi data penelitian yang diperlukan. ${ }^{7}$ Lewat jenis penelitian hukum normatif, penulis melakukan analisa kualitatif yang dimana penulis menyampaikan data-data yang didapat dalam bentuk kata-kata bukan dalam bentuk angka, yang didapat dari studi pustaka. Adapun peraturan perundang-undangan yang menjadi dasar dari penelitian penulis adalah Kitab Undang-Undang Hukum Perdata, Undang-Undang Nomor 8 Tahun 1999 tentang Perlindungan Konsumen, Undang-Undang Nomor 36 Tahun 2009 Tentang Kesehatan, Undang-Undang Nomor 11 Tahun 2008 Tentang Informasi dan Transaksi Elektronik, Peraturan Menteri Kesehatan Republik Indonesia Nomor 1175/Menkes/ Pers/VIII/2010 Tentang izin Produksi Kosmetika, Peraturan Menteri Kesehatan Republik Indonesia Nomor 1176/Menkes/ Pers/VIII/2010 Tentang Notifikasi Kosmetika dan Peraturan lainnya yang berlaku dan bersangkutan dengan objek penelitian.

\section{Hasil Penelitian dan Pembahasan}

\section{Tanggung Jawab Pihak yang Memproduksi dan Mengedarkan Kosmetik Ilegal di Indonesia.}

Tanggung jawab adalah seseorang atau sesuatu yang kehadiran atau perilakunya cenderung menyebabkan rasa malu atau menempatkan seseorang pada posisi yang tidak menguntungkan. Dalam hukum, tanggung jawab berarti bertanggung jawab wajib secara hukum.

\footnotetext{
${ }^{4}$ Abdulkadir Muhammad, Hukum dan Penelitian Hukum, Bandung: Citra Aditya Bakti, 2004, hlm. 32 .

${ }^{5}$ Amiruddin, dan Zainal Hasikin, Pengantar Metode Penelitian Hukum, Jakarta: Rajawali Pers, 2014, hlm 30.

6 Johnny Ibrahim, Teori dan Metodologi Penelitian Hukum Normatif, Surabaya:Bayumedia, Publishing, 2005

${ }^{7}$ Soerjono Soekanto dan Sri Mamudji, "Penelitian Hukum Normatif: Suatu Tinjauan Singkat”,(Jakarta: Rajawali Press, 2009, hlm. 23.
} 
Tanggung jawab hukum menyangkut hukum perdata dan hukum pidana dan dapat timbul dari berbagai bidang hukum, seperti kontrak, ganti rugi, pajak, atau denda yang diberikan oleh lembaga pemerintah. Pengadu adalah orang yang berupaya untuk menetapkan, atau membuktikan, tanggung jawab. Dalam KUH Perdata pasal 1365 yang berbunyi: “Tiap perbuatan yang melanggar hukum dan membawa kerugian kepada orang lain, mewajibkan orang yang menimbulkan kerugian itu karena kesalahannya untuk menggantikan kerugian tersebut."

Secara singkat, Kosmetik adalah produk yang digunakan untuk meningkatkan atau mengubah penampilan wajah, aroma atau tekstur tubuh. Banyak kosmetik yang dirancang untuk digunakan pada wajah dan tubuh. Mereka umumnya campuran senyawa kimia yang berasal dari sumber alami (seperti minyak kelapa), atau mungkin sintetis atau buatan.

Kosmetik yang diterapkan pada wajah untuk meningkatkan penampilan seseorang juga dikenal sebagai riasan yang mencakup barang-barang seperti; lipstik, maskara, eye shadow, foundation, blush on, highlighter, bronzer dan beberapa produk lainnya. Setiap produk kosmetik, termasuk perawatan pribadi dan peralatan mandi, yang diimpor ke dan dijual di Indonesia harus terdaftar terlebih dahulu. Registrasi produk kosmetik diatur oleh Badan Pengawasan Obat dan Makanan Nasional, juga dikenal sebagai Badan Pengawas Obat dan Makanan (BPOM). Sebagaimana diatur oleh BPOM, sebelum mendaftarkan produk harus mengajukan permohonan akses ke sistem online BPOM. Untuk itu, anda perlu mengirimkan aplikasi online bersama dengan dokumen pendukung yang diperlukan, setelah Anda mendapatkan akses ke BPOM.

Namun tanpa disadari, masyarakat Indonesia memiliki satu kebudayaan yang dapat dinilai sebagai kebudayaan yang buruk seperti halnya dalam proses registrasi ijin edar pada Badan Pengawas Obat dan Makanan (BPOM) cenderung mengabaikan dan merasa bahwa proses ijin edar yang dianjurkan oleh Badan Pengawas Obat dan Makanan (BPOM) sesuai dengan syaratnya tergolong tidak mudah dan memakan waktu yang lama, oleh karena hal tersebut mereka enggan untuk mengikuti peraturan yang ada karena tidak ingin mempersulit dirinya ataupun jalannya usahanya dan sering kali juga manusia mengganggap bahwa hukum yang ada di Indonesia kurang tegas, sehingga hal tersebut menghasilkan presepsi masyarakat yang melihat bahwa tidak mengikuti hukum yang ada adalah hal yang normal, maka terciptalah kebudayaan yang tidak baik bagi masyarakat itu sendiri.

Hal tersebut membuat sebagian produsen memilih untuk tidak mendaftarkan produknya tersebut dan akhirnya produsen tersebut memuat nomor izin edar yang palsu yang dimana nomor tersebut tidak melalui 
pesetujuan pendaftaran oleh pihak Badan Pengawas Obat dan Makanan (BPOM) dengan kata lain produk yang dibuat tidak diuji terlebih dahulu oleh pihak yang berwenang yaitu Badan Pengawas Obat dan Makanan (BPOM). Dengan kata lain produk tesebut bisa saja termasuk dalam kategori produk kosmetik yang berbahaya karena aromanya menyengat, teksturnya kental dan sulit meresap kemudian sering menjanjikan kulit cepat putih bersih dalam waktu singkat dan krim yang ditawarkan terkandung Merkuri yang pada umumnya dapat menyebabkan kerusakan pada syaraf seperti gangguan emosi, depresi, pikun bahkan insomnia, kemudian dapat memperlambat pertumbuhan janin bagi ibu yang mengandung, menyebabkan anak menjadi autisme hingga dapat mengakibatkan keguguran akibat dari merkuri yang sumbat dan menumpuk dalam tubuh dan berpengaruh kepada janin ibu yang mengandung, selain itu merkuri juga dapat merusak saluran pencernaan, merusak lapisan kulit bawah yang dapat mengakibatkan kanker pada kulit, kemudian kerusakan pada ginjal sehingga dapat mengakibatkan kematian akibat dari gagal ginjal.

Dalam pembahasan ini, tanggung jawab terhadap pihak yang memproduksi dan mengedarkan suatu produk kosmetik tanpa ada ijin edar serta produk yang diedarkan tidak sesuai dengan persyaratan dan keamanan yang telah ditentukan. Dan kosmetika merupakan salah satu sediaan farmasi maka orang tersebut dijerat dengan Pasal 196 dan 197 menyangkut dengan mutu sebagaimana dimaksud dalam Pasal 98 ayat (2) Undang-Undang Nomor 36 Tahun 2009 tentang Kesehatan yang berbunyi: "Setiap orang yang tidak memiliki keahlian dan kewenangan dilarang mengadakan, menyimpan, mengolah, mempromosikan, dan mengedarkan obat dan bahan yang berkhasiat obat.". Dan Pasal 98 ayat (3) UndangUndnag Nomor 36 Tahun 2009 tentang Kesehatan yang berbunyi : "Ketentuan mengenai pengadaan, penyimpanan, pengolahan, promosi, pengedaran sediaan farmasi dan alat kesehatan harus memenuhi standar mutu pelayanan farmasi yang ditetapkan dengan Peraturan Pemerintah."

Kemudian diatur bahwa berkenaan dengan sanksi dimana Setiap orang yang dengan sengaja memproduksi atau mengedarkan sediaan farmasi dan/atau alat kesehatan yang tidak memenuhi standar dan/atau persyaratan keamanan, khasiat atau kemanfaatan, dan mutu sebagaimana dimaksud dalam undang-undang dipidana dengan pidana penjara paling lama 10 (sepuluh) tahun dan denda paling banyak Rp1.000.000.000,00 (satu miliar rupiah). Dan serta Setiap orang yang dengan sengaja memproduksi atau mengedarkan sediaan farmasi dan/atau alat kesehatan yang tidak memiliki izin edar sebagaimana dimaksud dalam undangundang dipidana dengan pidana penjara paling lama 15 (lima belas) tahun 
dan denda paling banyak Rp1.500.000.000,00 (satu miliar lima ratus juta rupiah).

Oleh karena itu, sebagai seorang pelaku usaha tentunya sudah diberikan aturan dalam memproduksi hingga mengedekarkan sesuai dengan yang ditentukan menurut Pasal 19 Undang-Undang Nomor 8 Tahun 1999 tentang Perlindungan Konsumen adalah Tanggung jawab terhadap produk yang telah diedarkan atau dipasarkan yang menimbulkan kerugian atas kerusakaan dan kerugian akibat dari mengkonsumsi produk yang diperdagangkan, Ganti rugi yang dimaksud adalah memberikan ganti rugi berupa pengembalian uang atau penggantian barang dan memberikan santunan yang sesuai dengan ketentuan yang berlaku.

\section{Sanksi Kepada Pelaku Usaha yang Memasarkan dan Mengedarkan Kosmetik Ilegal secara Online di Indonesia.}

Setiap perkembangan industri kometik yang dipadu dengan teknologi yang canggih berbasis online tahun ke tahun selalu mengalami peningkatan, perpaduan tersebut membuat pihak pelaku usaha mengambil peluang untuk memproduksi kosmetik dan memasarkan produk kepada masyarakat yang menganggap bahwa produk kosmetik dan perawatan kulit sebagainya adalah hal penting bagi masyarakat modern sekarang ini, dari ujung rambut sampai ke ujung kaki terdapat masing-masing perawatan kulit tersendiri, karena kebutuhan terhadap kosmetik semakin dibutuhkan.

Namun perkembangan tersebut tentunya akan melahirkan dampak negatif terhadap pekembangan transaksi secara e-commerce di Negara Indonesia seperti contohnya penipuan kartu kredit, pencurian identitas, peretasan, situs web palsu, dan produk palsu. Disini kita akan membahas salah satu dampak negatifnya yaitu produk palsu seiring dengan produk kosmetik sekarang banyak yang tidak terdaftar, mengadung zat berbahaya tetapi banyak diedarkan dipasaran maupun di Online. Apabila membuat suatu iklan tentunya harus didasari dengan peraturan Undang-Undang Nomor 8 Tahun 1999 tentang Perlindungan Konsumen, Pasal 17 yang dimana mengatur tentang bagaimana cara seorang pelaku usaha periklanan yang mengiklankan produknya secara benar dan hal apa yang tidak boleh dilakukan, seperti: 1) Mengelabui konsumen mengenai kualitas, kuantitas, bahan, kegunaan dan harga barang dan/atau tarif jasa serta ketepatan waktu penerimaan barang dan/atau jasa; 2) Memuat informasi yang keliru, salah, atau tidak tepat mengenai barang dan/atau jasa; 3) Tidak memuat informasi mengenai risiko pemakaian barang 
dan/atau jasa; 4) Melanggar etika dan/atau ketentuan peraturan perundang-undangan mengenai periklanan.

Faktanya, banyak sekali pelaku usaha di Indonesia yang melanggar perbuatan-perbuatan yang dilarang seperti memproduksi, memasarkan dan mengiklankan semena-mena tanpa menghiraukan hukum yang telah diatur oleh negaranya sendiri dan menimbulkan akibat yang fatal serta tidak mau bertanggungjawab terhadap segala kerugian yang dialami pihak konsumen, yang sudah diatur larangan yang harus dituruti oleh para pelaku usaha sebagaimana dalam Pasal 9 Undang-Undang Nomor 8 Tahun 1999 tentang Perlindungan Konsumen dan apabila sebagai seorang pelaku usaha melanggar peraturan yang tertulis terkait dengan pelaku usaha periklanan dan ganti rugi yang dapat dibuktikan oleh konsumen maka dikenakan sanksi administratif apabila melanggar Pasal 19 ayat (2) dan ayat (3), Pasal 20, Pasal 25, dan Pasal 26, akan ditetapkan sanksi administratif yaitu ganti rugi paling banyak Rp 200.000.000 dan Sanksi Pidanaterhadap pelaku usaha sebagaimana dimaksud dalam Pasal 8, Pasal 9, Pasal 10, Pasal 13 ayat (2), Pasal 15, Pasal 17 ayat 1) huruf a, huruf b, huruf c, huruf e, ayat (2), dan Pasal 18 dipidana dengan pidana penjara paling lama 5 (lima) tahun atau pidana denda paling banyak Rp 2.000.000.000 serta Pelaku usaha yang melanggar Pasal 11, Pasal 12, Pasal 13 ayat (1), Pasal 14, Pasal 16, dan Pasal 17 ayat (1) huruf d dan huruf f dipidana dengan pidana penjara paling lama 2 (dua) tahun atau pidana denda paling banyak Rp 500.000.000.

Selain dari pada Undang-Undang Nomor 8 Tahun 1999, apabila pelanggaran yang dibuat melahirkan unsur-unsur perbuatan melawan hukum maka sanksi yang dapat diberikan akan dikaitkan dengan Pasal 1365, 1366 dan 1367 KUH Perdata yang masing-masing berbunyi:

Pasal 1365 KUH Perdata :

"Tiap perbuatan yang melanggar hukum dan membawa kerugian kepada orang lain, mewajibkan orang yang menimbulkan kerugian itu karena kesalahannya untuk menggantikan kerugian tersebut."

Pasal 1366 KUH Perdata :

"Setiap orang bertanggung jawab tidak saja untuk kerugian yang disebabkan perbuatannya, tetapi juga untuk kerugian yang disebabkan kelalaian atau kurang hati-hatiannya." 
Pasal 1367 KUH Perdata :

"Seorang tidak saja bertanggung jawab untuk kerugian yang disebabkan perbuatannya sendiri, tetapi juga untuk kerugian yang disebabkan perbuatan orang-orang yang menjadi tanggungannya atau disebabkan oleh barang-barang yang berada di bawah pengawasannya."

Dalam Undang-Undang Nomor 11 Tahun 2008 tentang Informasi dan Transaksi Elektronik menyatakan bahwa transaksi elektronik merupakan perbuatan hukum yang dilakukan dengan menggunakan Komputer, jaringan Komputer, dan/atau media elektronik lainnya. Apabila pelaku usaha dalam melakukan transaksi jual beli kepada seorang konsumen dengan menggunakan alat elektronik, pelaku usaha wajib beriktikad baik dan meberikan informasi sebenar-benarnya agar tidak menimbulkan kerugian yang tidak diinginkan selama transaksi berlangsung sesuai dengan pasal 28, yang berbunyi, "Setiap Orang dengan sengaja dan tanpa hak menyebarkan berita bohong dan menyesatkan yang mengakibatkan kerugian konsumen dalam Transaksi Elektronik."

Apabila pelaku tersebut tidak memenuhi pasal 28 Undang-Undang Nomor 11 Tahun 2008 tentang Informasi dan Transaksi Elektronik akan diberikan sanksi sesuai dengan pasal 45 ayat (2) yang berbunyi: "Setiap Orang yang memenuhi unsur sebagaimana dimaksud dalam Pasal 28 ayat (1) atau ayat (2) dipidana dengan pidana penjara paling lama 6 (enam) tahun dan/atau denda paling banyak Rp1.000.000.000,00 (satu miliar rupiah)."

Maka dari hal itu, diharapkan kepada semua pelaku usaha yang menjalani bisnisnya dengan memasarkan dan melakukan transaksi jual beli secara online untuk mematuhi segala peraturan yang telah diatur dalam negara Indonesia yakni negara kita sendiri dan tidak melakukan pelanggaran atau perbuat hukum yang mengakibatkan para pihak mengalami kerugian serta dapat tercapai keadilan dan kesejahteraan bagi seluruh rakyatnya.

\section{Perlindungan Hukum terhadap Konsumen yang Mengalami Kerugian Akibat Pemakaian Kosmetik Ilegal di Indonesia.}

Mengingat Pasal 5 dalam Undang-Undang Perlindungan Konsumen tentang kewajiban konsumen yang berbunyi, "Membaca atau mengikuti petunjuk informasi dan prosedur pemakaian atau pemanfaatan barang dan/atau jasa, demi keamanan dan keselamatan." 
Namun apabila seorang konsumen telah melaksanakan kewajiibannya sebagai seorang konsumen dan ternyata konsumen tersebu mengalami kerugian akibat tipu daya dari pihak pelaku usaha yang menawarkan produk kepada konsumennya maka tidak terciptalah keseimbangan yang dimana peraturan tentang perlindungan konsumen lahir karena hal tersebut. Didasari dengan Pasal 1 ayat (4) dan Pasal 106 Undang-Undang Nomor 36 tentang Kesehatan pasal yang berbunyi: Sediaan farmasi adalah obat, Bahan obat, obat tradisional, dan Kosmetika hanya dapat diedarkan setelah mendapat izin edar dimana penandaan dan informasi sediaan farmasi dan alat kesehatan harus memenuhi persyaratan objektivitas dan kelengkapan serta tidak menyesatkan.

Terkait dengan aturan yang telah diatur dalam membuat sediaan farmasi yaitu kosmetika harus sesuai dengan standar mutu serta syarat yang ditentukan dan mendapat ijin edar. Tetapi bagaimana dengan sebagian produsen atau pelaku usaha yang panjang menganggap bahwa pendaftaran untuk mendapatkan ijin berserta biaya-biaya yang harus dikeluarkan membuat sebagian produsen rumit, mahal dan lama, akhirnya produsen tersebut memuat nomor izin edar yang palsu yang dimana nomor tersebut tidak melalui pesetujuan pendaftaran oleh pihak Badan Pengawas Obat dan Makanan (BPOM) dengan kata lain produk yang dibuat tidak diuji terlebih dahulu oleh pihak yang berwenang yaitu Badan Pengawas Obat dan Makanan (BPOM).

Menurut Pasal 19 ayat (1) tentang Undang-Undang Perlindungan Konsumen yang menyebutkan bahwa pelaku usaha bertanggung jawab untuk memberikan kompensasi atas kerusakan, polusi, dan / atau kerugian konsumen karena barang dan / atau jasa yang dikonsumsi atau diproduksi. Sistem liabilitas yang terkandung dalam garis besar Undang-Undang Perlindungan Konsumen adalah liabilitas sistem kesalahan, di mana ada kebutuhan untuk membuktikan elemen kesalahan.

Tanggung jawab kesalahan dengan pembalikan beban bukti yang dipegang oleh Undang-Undang Perlindungan Konsumen menyiratkan bahwa kewajiban untuk membuktikan apakah ada unsur kesalahan ada pada pelaku usaha. Ketika seorang pelaku usaha tidak dapat membuktikan bahwa ia tidak bersalah atau telah terbukti bersalah, maka pelaku usaha tersebut wajib memberikan kompensasi kepada konsumen. Sistem pertanggungjawaban atas kesalahan dengan pembalikan beban pembuktian secara eksplisit didefinisikan dalam Pasal 28 Undang-Undang Perlindungan Konsumen yang berbunyi, "Bukti ada tidaknya unsur kesalahan dalam klaim kompensasi sebagaimana dimaksud dalam Pasal 19, Pasal 22, Pasal 23 menjadi beban dan tanggung jawab pelaku usaha." 
Pertanggungjawaban kesalahan dengan membalikkan beban bukti adalah bentuk pertanggungjawaban yang dipertajam, dengan sistem ini posisi konsumen yang kurang beruntung diperkuat dengan tidak mengabaikan unsur-unsur pertanggungjawaban. Perlindungan hukum khusus untuk konsumen kosmetik melalui perdagangan online, dalam Pasal 65 ayat (3) Undang-Undang Perdagangan, telah menyatakan bahwa dalam hal terjadi perselisihan terkait transaksi perdagangan melalui sistem elektronik, seorang penduduk atau badan usaha dapat menyelesaikan sengketa melalui pengadilan atau melalui mekanisme dengan bentuk penyelesaian sengketa lainnya.

Dengan demikian perlindungan hukum yang represif terhadap konsumen kosmetik melalui perdagangan online dapat didasarkan pada mekanisme peradilan dengan mengajukan gugatan berdasarkan Pasal 1365 BW atau berdasarkan Pasal 28 UU Perlindungan Konsumen, yaitu terkait dengan akuntabilitas dengan bukti terbalik. Perlindungan hukum yang represif melalui upaya hukum administrasi dalam melaporkan tindakan entitas perdagangan online kepada Bupati atau Walikota yang berwenang dalam menerbitkan SIUP dan TDP harus ditindaklanjuti dengan penangguhan kegiatan bisnis dan pencabutan izin sebagaimana dinyatakan dalam pasal 65 ayat (3) Undang-Undang Perdagangan.

Perlindungan hukum melalui prosedur pidana dapat dilakukan dengan melaporkannya kepada Polisi, untuk ditindaklanjuti dengan penyelidikan dasn proses konfirmasi sesuai dengan ketentuan KUH Perdata, UndangUndang Nomor 36 Tahun 2009 tentang Kesehatan yaitu dengan Pasal 196 dan 197 yang berbunyi:

Pasal 196 UU 36 Tahun 2009 : "Setiap orang yang dengan sengaja memproduksi atau mengedarkan sediaan farmasi dan/atau alat kesehatan yang tidak memenuhi standar dan/atau persyaratan keamanan, khasiat atau kemanfaatan, dan mutu sebagaimana dimaksud dalam Pasal 98 ayat (2) dan ayat (3) dipidana dengan pidana penjara paling lama 10 (sepuluh) tahun dan denda paling banyak Rp1.000.000.000,00 (satu miliar rupiah)."

Pasal 197 UU 36 Tahun 2009: "Setiap orang yang dengan sengaja memproduksi atau mengedarkan sediaan farmasi dan/atau alat kesehatan yang tidak memiliki izin edar sebagaimana dimaksud dalam Pasal 106 ayat (1) dipidana dengan pidana penjara paling lama 15 (lima belas) tahun dan denda paling banyak Rp1.500.000.000,00 (satu miliar lima ratus juta rupiah)." 
Kemudian dengan Pasal 4 Undang-Undang tentang Perlindungan Konsumen menyatakan sebagai seorang konsumen berhak mendapatkan informasi yang benar dan pelaku usaha tidak menjalankan kewajibannya dengan itikad baik dan produk yang dijual tidak memenuhi standarnya maka melanggar beberapa Pasal dalam Undang-Undang Perlindungan Konsumen Nomor 8 Tahun 1999 dan dijerat Pasal 62 ayat (1) dan (2) mengenai sanksi pidana, yang berbunyi:

Pasal 62 ayat (1) UU 8 Tahun 1999:

"Pelaku usaha yang melanggar ketentuan sebagaimana dimaksud dalam Pasal 8, Pasal 9, Pasal 10, Pasal 13 ayat (2), Pasal 15, Pasal 17 ayat (1) huruf a, huruf b, huruf c, huruf e, ayat (2), dan Pasal 18 dipidana dengan pidana penjara paling lama 5 (lima) tahun atau pidana denda paling banyak Rp 2.000.000.000,00 (dua miliar rupiah)."

Pasal 62 ayat (2) UU 8 Tahun 1999:

"Pelaku usaha yang melanggar ketentuan sebagaimana dimaksud dalam Pasal 11, Pasal 12, Pasal 13 ayat (1), Pasal 14, Pasal 16, dan Pasal 17 ayat (1) huruf d dan huruf $f$ dipidana dengan pidana penjara paling lama 2 (dua) tahun atau pidana denda paling banyak Rp 500.000.000,00 (lima ratus juta rupiah).

Sebagai seorang Pelaku Usaha dalam membangun bisnis seharusnya didasari dengan itikad yang baik agar dikemudian hari memperoleh rezeki yang baik juga dan tentunya pertanggung jawaban atas memberikan informasi yang benar, jelas, dan jujur mengenai barang diperdagangkan berdasarkan ketentuan standar mutu barang dan memberikan ganti rugi akibat dari penggunaan barang tersebut wajib dilaksanakan dan bukan sebaliknya, melarikan diri dari pertanggung jawabannya sesuai dengan kewajiban sebagai seorang pelaku usaha yang tertulis pada pasal 7 Undang- Undang Perlindungan Konsumen. Kemudian mengacu pada transaksi jual dan beli yang kerap dilakukan oleh para produsen atau pelaku usaha dengan tujuan mendapatkan konsumen dengan yang cara mudah tetapi kemajuan teknologi tersebut disalah gunakan oleh pelaku usaha untuk melakukan transaksi jual beli produk kosmetik dan tidak memberikan informasi yang jelas dan terhadap produk yang ditawarkan oleh pihak pelaku usaha maka pelaku usaha telah melanggar aturan Pasal 9 Undang- Undang Nomor 11 Tahun 2008 tentang Informasi dan Transaksi Elektronik yang berbunyi: "Pelaku usaha yang menawarkan produk melalui Sistem Elektronik harus menyediakan informasi yang lengkap dan benar berkaitan dengan syarat kontrak, produsen, dan produk yang ditawarkan." 


\section{E. Penutup}

Dari hasil penelitian dan pembahasan yang telah dilakukan oleh peneliti, maka dapat ditarik kesimpulan sebagai berikut:

1. Penerapan Dalam memutuskan untuk membeli suatu barang, kita harus mempertimbangkan banyak hal, seperti dalam produk kosmetik yang dipasarkan ternyata mengandung bahan berbahaya yang dapat merusak organ tubuh manusia, kemudian tidak berlabel ataupun tidak memiliki tanggal kadaluarsa produk dan informasi lainnya yang benar, dan kita tidak tahu benar alasan produk tersebut dijual murah selain itu, kebanyakan produk yang berbahaya dan palsu sering kali dijual dan ditemukan tidak memiliki nomor ijin dari Badan Pengawas Obat dan Makanan (BPOM), yang dimaksud berbahaya disni adalah produk kosmetik seperti krim yang terkandung Merkuri, pada umumnya dapat menyebabkan kerusakan pada syaraf seperti gangguan emosi, depresi, pikun bahkan insomnia, kemudian dapat memperlambat pertumbuhan janin bagi ibu yang mengandung, menyebabkan anak menjadi autisme hingga dapat mengakibatkan keguguran akibat dari merkuri yang sumbat dan menumpuk dalam tubuh dan berpengaruh kepada janin ibu yang mengandung, selain itu merkuri juga dapat merusak saluran pencernaan, merusak lapisan kulit bawah yang dapat mengakibatkan kanker pada kulit, kemudian kerusakan pada ginjal sehingga dapat mengakibatkan kematian akibat dari gagal ginjal. Pada tahap ini, Undang-Undang Nomor 8 Tahun 1999 tentang Perlindungan Konsumen berperan untuk memberikan perlindungan hukum kepada konsumen yang telah menjadi korban akibat produk kosmetik yang berbahaya yang dijual oleh pelaku usaha.

2. Sanksi yang diberikan kepada pelaku usaha yang memasarkan dan mengedarkan suatu produk kosmetik tanpa ada ijin edar serta produk yang diedarkan tidak sesuai dengan persyaratan dan keamanan yang telah ditentukan maka orang tersebut dijerat dengan Pasal 196 menyangkut dengan mutu sebagaimana dimaksud dalamPasal 98 ayat (2) dan ayat (3) Undang-Undang tentang Kesehatan maka akan dipidana dengan hukuman penjara paling lama 10 tahun dan denda paling Rp. 1.000.000.000,00 (satu miliar rupiah), sedangkan pada Pasal 197 menyatakan bahwa setiap orang atau pihak yang dengan sengaja memproduksi atau mengedarkan sediaan suatu produk kosmetik dan tidak memiliki izin edar maka sebagaimana dimaksud dalam Pasal 106 ayat (1) dipidana dengan hukuman pidana penjara paling lama 15 (lima belas) tahun dan denda paling banyak Rp.1.500.000.000,00 (satu miliar lima ratus juta rupiah). Merujuk pada Undang- Undang Nomor 11 Tahun 2008 tentang Informasi dan Transaksi Elektronik yang menyatakan apabila pelaku usaha melanggar maka akan dikenakan sanksi sesuai dengan aturan yang berlaku. 
3. Perlindungan hukum yang diberikan kepada konsumen represif terhadap konsumen kosmetik melalui perdagangan online dapat didasarkan pada mekanisme peradilan dengan mengajukan gugatan untuk menyelesaikan sengketa dan mendapatkan sanski berdasarkan Pasal 1365 BW atau berdasarkan Undang-Undang Nomor 8 Tahun 1999 Tentang Perlindungan Konsumen, Undang-Undang Nomor 36 Tahun 2009 Tentang Kesehatan.

\section{DAFTAR PUSTAKA}

Amiruddin, dan Zainal Hasikin. (2014). Pengantar Metode Penelitian Hukum. Jakarta: Rajawali Pers

Ibrahim, Johnny. (2005). Teori dan Metodologi Penelitian hukum Normatif. Surabaya: Bayumedia Publishing.

Soekanto, Soerjono dan Sri Mamudji. (2009). Penelitian Hukum Normatif: Suatu Tinjauan Singkat. Jakarta: Rajawali Press

Muhammad, Abdulkadir. (2004). Hukum dan Penelitian Hukum. Bandung: Citra Aditya Bakti. 